\title{
América Latina - entre heróis E CARNAVAIS: O LABERINTO E A CARROZa de Simón Bolívar*
}

\author{
América Latina - ENTre héroes y \\ CARnAVAlES: El LABERINTO Y LA CARROZA DE \\ Simón Bolívar
}

Hugo Eliecer Dorado Mendez ${ }^{1}$

* Artículo derivado de la investigación "O descontrucionismo pleno ao redor da figura de Simón Bolívar em La Carroza de Bolivar (2012) e La Visita de Bolivar (2018)", del Grupo Ressignificações do assado na América: Leitura, escrita e tradução de géneros híbridos de histórica e ficção-vias para a descolonização.

Cómo citar este artículo: Dorado Mendez, H. E. (2020). América Latina - entre heróis e carnavais: o Laberinto e a Carroza de Simón Bolívar. Estudios de Literatura Colombiana 46 pp. 55-74. DOI: https://doi.org/10.17533/ udea.elc.n46a03

${ }^{1}$ https://orcid.org/0000-0002-8613-8136 felipebemol@hotmail.com

Universidade Federal da Integração LatinoAmericana, Brasil

Editores: Andrés Vergara Aguirre, Christian Benavides Martínes, Vanessa Zuleta Quintero

Recibido: 15.08 .2019

Aprobado: 21.10.2019

Publicado: 27.12.2019

Copyright: (2020 Estudios de Literatura Colombiana. Este es un artículo de acceso abierto distribuido bajo los términos de la Licencia Creative Commons AtribuciónNo comercial - Compartir igual 4.0 Internacional
Resumo: Este trabalho visa construir uma análise crítica das obras El General en su laberinto (1989) y La carroza de Bolivar (2012) sob a luz das teorias literárias contemporâneas. Partimos da hipótese de que as obras, por meio de determinadas estrategias escriturais e discursivas desconstrucionistas, projetam, na tessitura narrativa, dois novos paradigmas ao redor da figura do General: a redimensionalização no plano heroico de um Bolívar humanizado e latinoamericanizado em El general; e a desconstrução total desse perfil heroico a partir da carnavalização e da parodia em La carroza.

Palavras-chave: Simón Bolívar; romance histórico; níveis de desconstrução; literatura e história.

Resumen: este trabajo busca construir un análisis crítico de las obras El General en su laberinto (1989) y La carroza de Bolívar (2012) a la luz de las teorías literarias contemporáneas. Partimos de la hipótesis de que las obras, por medio de determinadas estrategias escriturales y discursivas deconstruccionistas, proyectan, en la tesitura narrativa, dos nuevos paradigmas alrededor de la figura del General: la redimensionalización en el plano heroico de un Bolívar humanizado y latinoamericanizado en El general; y la deconstrucción total de ese perfil sublime a partir de la carnavalización y de la parodia en La carroza.

Palabras clave: Simón Bolívar; novela histórica; niveles de deconstrucción; literatura e historia. 


\section{Introdução}

O extenso território latino-americano e os distintos povos que aqui habitam possuem uma intensa e significativa história de luta e resistência. A chegada arrasadora dos colonizadores europeus, episódio histórico que marca o início da existência do chamado Novo Mundo para a historiografia - mas não o começo da nossa civilização, que ativamente se desenvolvia neste território muito antes da chegada dos colonizadores e conquistadores vindos das metrópoles europeias - provoca um violento choque histórico-cultural que repercutiria, incessantemente, na trajetória política, econômica, social, cultural e religiosa dos povos destas terras até a atualidade. Esse capítulo histórico, que seria o marco de início da era moderna, fim do estreito pensamento medieval e o começo da maior expansão territorial dos povos europeus ocidentais, teria, em contrapartida, implicações devastadoras no nosso território.

A descoberta, conquista e sucessiva colonização territorial e ideológica iniciadas com a vinda das expedições espanhola, comandada por Cristóvão Colombo em 1492, e portuguesa, liderada por Cabral em 1500, entre outras, significaram, no contexto americano, um enfrentamento histórico inapagável da nossa memória. O impacto provocado pelo encontro de mundos tão diferentes ficaria registrado como um episódio funesto na memória de uns, os colonizados, ou como um dia glorioso na memória dos outros, os colonizadores.

O processo de conquista e colonização, árduo e intrincado, esteve marcado mormente pela resistência dos autóctones e pelas ações incessantes do colonizador por estabelecer seu domínio sobre a terra e sua gente. Com o passar dos anos, essa soberania europeia foi se acentuando nas distintas regiões da América que passaram a ser colônias exploradas, produtoras de matérias primas e riquezas minerais. Desse modo, a escrita da história desses períodos - conquista e colonização, em especial - consignou, num longo primeiro momento, apenas a visão dos conquistadores que, ao terem o domínio da escrita, erigiam imagens exaltadoras e heroicas de suas próprias ações ou daquelas de seus companheiros.

No entanto, depois de vários séculos de subjugação, exploração, domínio europeu e aculturação dos povos nativos no nosso território, outro episódio histórico, tão significativo e marcante quanto o da descoberta e da colonização, viria estalar e irromper-se por essas terras: os processos de independência e descolonização territorial. 
Grandes movimentos civis armados surgiriam nas distintas regiões do continente, desencadeando diversas revoltas, guerras e revoluções que visavam à independência dos territórios e à expulsão das metrópoles colonizadoras dominantes. Esses movimentos independentistas, que se estenderam pelos séculos XVIII e XIX, tiveram as suas particularidades em cada região onde se originaram, contando, cada um deles, com um matiz singular e diferenciado no seu andamento. Os movimentos libertários de independência tiveram, em geral, uma natureza conflituosa e agitada em todo o território continental, porém, o modus operandi dos povos que lutaram pela sua liberdade divergiu de acordo com múltiplos fatores históricos e culturais. De qualquer forma, a evidente insustentabilidade dos regimes colonizadores que subjugavam, exploravam e controlavam o território continental desencadeou uma série de ações históricas que resultariam na independência dos povos colonizados e na fundação de nações autônomas no continente americano.

\section{O projeto literário latino-americano a partir dos heróis da independência}

Uma nova transformação sociocultural estalava na América e, nesse contexto conturbado de guerras e revoluções, surgiram líderes intelectuais, sociais e militares que dirigiram as campanhas independentistas nos diversos territórios deste continente. Miguel Hidalgo, com “el Grito de Dolores” no México; José de San Martín, na região rio-platense; José Condorcanqui - chamado Túpac Amaru - líder da maior revolta indígena anticolonial no Peru; George Washington, com as campanhas militares das treze colônias britânicas; Policarpa Salavarrieta - la Pola - mulher símbolo de valentia e coragem nas guerras da independência colombiana; Jean-Jacques Dessalines, líder da revolução que resultaria na formação da primeira nação latino-americana independente, Haiti; Simón Bolívar, com a empreitada independentista por toda a região andina; José Martí, líder intelectual e político da "Guerra del 95" em Cuba; entre muitos outros, foram personagens que se levantaram para encabeçar o segundo maior episódio histórico do continente americano. A relevância desses homens e mulheres nos processos de independência - seja pelas contribuições intelectuais, políticas, militares ou sociais — valeu-lhes o título de heróis da independência. 
Tais emblemáticas figuras, no decorrer dos anos, transformaram-se em fontes históricas nas quais os povos de nossas terras procuram autênticas expressões da busca pela liberdade, da valentia, do que é nosso. As vidas e os feitos desses "heróis" intervieram determinantemente no imaginário das gentes que aqui habitam e, consequentemente, têm influenciado no desenvolvimento social, político e econômico das nações americanas.

No afã de construir as memórias das nações recém-formadas dando-lhes seus heróis, entre conflitos internos, disputas e divergências, a recente historiografia latino-americana adotou, como também o fez a literatura, os mesmos procedimentos das escritas canônicas europeias. Assim, não foram reservados os traços de heroísmo, coragem, determinação, valentia e outros aspectos heroificadores para a construção discursiva desses sujeitos. Foram eles exaltados ao máximo, da mesma forma como foram pelo discurso europeu os conquistadores e colonizadores. Houve, nesse sentido, pouca preocupação com relação à verificação exaustiva de suas trajetórias e atos, pois as novas repúblicas - que se transformariam também em ditaduras - necessitavam de heróis para se consolidarem. Para Claudia Wasserman (2011), durante esse período, "os historiadores atuaram, de fato, como legitimadores dos projetos de construção nacional propugnados pelas elites oligárquicas”(p. 97).

Tamanho acontecimento histórico deixou uma abundante gama de personagens e histórias as quais seriam aproveitadas também pela arte romanesca para a produção de múltiplas representações literárias. Literatos das distintas regiões do continente valeram-se dos recursos escriturais e discursivos próprios dos gêneros híbridos que transitam entre a história e a ficção para expor a sua visão do passado, baseados na sua experiência intelectual, nas memórias dos seus conterrâneos e, claro, na história oficial.

Desde o começo, esse contato entre ficção e história na arte romanesca deu-se, na América Latina, de forma singular e diferenciada do modelo europeu. É o caso, por exemplo, do primeiro romance histórico escrito em língua espanhola, Xicoténcatl (1826) — obra que antecede, ainda, as produções neste gênero escritas na Espanha -, o qual é,

[...] um claro exemplo de como o pensamento latino-americano se posicionou criticamente frente às imposições do cânone europeu - evidenciadas na modalidade clássica de romance histórico scottiana - já no Romantismo e [...] deu início ao processo de questionamento da sua formação histórica, já a inícios do século xIx, fato que é a essência da escrita do novo romance histórico latinoamericano, mais de um século depois (González e Fleck, 2017, p. IIG). 
Portanto, no nosso território, o romance histórico, gênero que exerce o papel da literatura como possível leitora da história, cultivou produções com matizes críticos e particulares, próprios de um universo amplamente diferenciado do europeu. Isso não só nas produções plenamente subversivas em relação à história - pertencentes às modalidades do novo romance histórico latino-americano e da metaficção historiográfica -, mas, inclusive, em muitas das obras que são catalogadas pela academia nas fases acríticas - como os romances históricos tradicionais, cujo discurso estaria em consonância com a historiografia oficial - as quais também possuem complexas composições discursivas que deixam entrever, muitas vezes, uma clara discordância entre a visão eurocêntrica da história e as perspectivas resultantes do fazer intelectual no nosso continente.

Ante tal amálgama de vozes que buscam, por meio da escrita romanesca misturada à história, refletir sobre o seu passado e a essência da sua identidade, as figuras da independência adquirem ampla relevância, pois se tornam estandartes de liberdade e modelos de identidade a serem seguidos. Assim, a construção do caráter heroico dessas figuras singulares que lutaram na independência se torna, em um primeiro momento da história, essencial à edificação de um discurso próprio. A junção dos discursos historiográfico e literário, reforçada pela arte e as manifestações populares, encarrega-se de escolher, arquitetar e erigir personagens, retratando seus grandes feitos nos processos de independência e, assim, reveste-os com véus heroicos. Esses heróis latino-americanos, então, passam a representar a contraposição do homem latino-americano frente ao europeu, ao colonizador, embora a ideologia discursiva que os edifica seja muito semelhante.

Com o surgimento, na América Latina, da segunda fase do romance histórico - fases esquematizadas na obra de Fleck (2017) —, que abarca as múltiplas expressões do novo romance histórico latino-americano e da metaficção historiográfica, revelam-se novas perspectivas de releitura crítica da história pela ficção. Essas releem, também, os acontecimentos do período da independência americana e buscam rever a caminhada daqueles heróis sacralizados no discurso historiográfico a partir de uma concepção descentralizadora.

Ao tratar da temática da independência, o novo romance histórico latinoamericano busca, essencialmente, ampliar o conjunto de vozes e visões que compõem 
os relatos daquele episódio histórico consignado nas páginas da história que edificou seus heróis e descentralizar o discurso, separando, assim, as múltiplas perspectivas ficcionais daquilo que a história proclamou como "verdade". Somado a isto, nessas produções híbridas que discursam ao redor das figuras heroicas do período da independência, busca-se mostrar outra faceta desses personagens, recriados a partir das perspectivas marginais. Desse modo, o caráter subversivo dos romances históricos da fase crítica do gênero, ao qual faz referência Aínsa (1991), entre outros estudiosos do gênero, irá ser perceptível, nas produções que abordam esta temática. Isso se dá não na crítica ao processo de independência em si, mas na revisão, desconstrução ou/e humanização dos heróis construídos e dos heróis esquecidos.

Isso posto, podemos, agora, centrar-nos em um dos considerados heróis de dito episódio histórico cuja figura e feitos têm sido mormente retratados e reiteradamente revisitados pela arte romanesca: Simón Bolívar. A sua importância e influência militar e política nos processos de independência e formação das nações latino-americanas, seu legado de luta e resistência e, também, de corrupção e autoritarismo, e o seu modo controvertido de pensar e agir, entre outros múltiplos aspectos, forneceram um amplo campo de inspiração para a produção literária da qual na sequência nos ocupamos.

\section{Bolívar, o Libertador, e suas distintas facetas: ressignificações na arte literária}

A vida e os feitos de Simón Bolívar — desde seu nascimento, no ano de 1783, até o dia da sua morte, em 17 de dezembro de 1830 - foram perpetuados historicamente nos diversos campos de estudo pela sua relevância no que concerne, principalmente, às guerras da independência e à libertação das Américas da dominação espanhola.

A historiografia neste continente, valendo-se de documentos, relatos e arquivos da época, arquitetou uma imagem do libertador que seria eternizada no imaginário latino-americano: a figura do "homem de ferro", inquebrantável no seu caráter, força e ânimo. Essa composição heroica do General foi reforçada em distintas áreas do conhecimento humano. Nas artes plásticas, por exemplo, produziram-se retratos e esculturas que mostravam o "herói das Américas" sobre seu belo e valoroso cavalo Palomo Blanco, sublime e idealizado, combatendo os espanhóis. 
Muitos são os romances históricos que surgiram na América Latina ao redor da vida e dos feitos de Bolívar e cada um deles espelha, como bem disse Cobo Borda (1989), um Bolívar distinto, fruto das reflexões dos povos americanos que buscam, por meio da arte literária e da revisão histórica, parte da essência das suas identidades (p. 7). Assim, podemos encontrar no repertório literário de romances históricos na América Latina concernentes à figura de Bolívar produções de diversa índole. Essas vão desde as manifestações mais românticas e tradicionais, passando pelas mais estritas no tocante ao criticismo frente ao discurso historiográfico, até as mais subversivas em relação a ele. Em outras palavras, o acervo de representações romanescas sobre a figura de Simón Bolívar, dentro do gênero do romance histórico, passa por cada uma das fases descritas pelos teóricos literários de dito gênero, a saber, segundo Fleck (2017), as fases acrítica, crítica e de mediação e suas respectivas modalidades.

Em vista da quantidade considerável de narrativas que abordam a temática, daremos, no presente estudo, ênfase a duas delas: El General en su laberinto (1989), do Nobel de literatura Gabriel García Márquez e La carroza de Bolívar (2012), do também colombiano Evelio Rosero. Ambas as obras são compreendidas pela academia como romances históricos ideologicamente críticos, isto é, produções híbridas que se confrontam com o discurso da historiografia. Assim sendo, focar-nos-emos, em seguida, na análise de duas obras latino-americanas contemporâneas que - cada uma por meio de recursos escriturais e ideológicos distintos e com intenções divergentes - refutarão a univocidade da voz da história e da literatura de cunho tradicionalista acerca do chamado Libertador das Américas.

\section{El General en su laberinto (1989): a redimensionalização do herói ao patamar humano}

Considerada uma das obras primas no que tange à releitura histórica da figura de Bolívar, El General en su laberinto (1989) surge no contexto latino-americano da mão do renomado Nobel de literatura Gabriel García Márquez. O literato colombiano publica o seu único romance histórico no período de auge dos que seriam logo catalogados como novos romances históricos latino-americanos por teóricos como Aínsa (1991) e Menton (1993), entre outros. 
A obra de García Márquez pressupõe a tentativa de reconfigurar ficcionalmente os últimos meses de vida do general Simón Bolívar, desde sua saída da capital colombiana, rumo ao exílio, na Europa. Assim, o foco está na sua viagem pelo grande rio Magdalena, até seus dias finais e morte. $\mathrm{O}$ romance, apesar do momento histórico no qual se publica, não é considerado unanimemente pela crítica como parte das produções do novo romance histórico latino-americano, devido, principalmente, ao seu viés discursivo ideológico na configuração da imagem de Bolívar. A obra tem suscitado diversas críticas a respeito da sua possível classificação, ancoradas nas teorias sobre o romance histórico clássico scottiano (Lukács, 1977), o novo romance histórico latino-americano (Menton, 1993), ou a metaficção historiográfica (Hutcheon, 1991). É importante salientar que a visão dos leitores críticos das décadas passadas estava ainda condicionada pelas teorias disponíveis naquele momento, as quais, se bem ofereciam alguns parâmetros norteadores na análise de romances históricos, não possuíam uma compreensão abrangente da escrita do gênero na América Latina. Essa amplitude da dimensão do conhecimento só vem a ser esquematizada nos anos recentes em obras como a de Fleck (2017), na qual se estabelecem as fases e as modalidades desse tipo de escrita híbrida.

Seymour Menton (1993) assinala a excessiva linearidade do enredo, a falta de experimentalismo formal, a presença de um só narrador heterodiegético, a quase nula polifonia e, ainda, o questionável apego ao discurso historiográfico em relação à caminhada da figura histórica, entre outros aspectos, para não considerar uma determinada obra, entre elas o romance de García Márquez (1989), dentro dos parâmetros do que seria o novo romance histórico latino-americano (pp. 25-39).

As afirmações do teórico canadense possuem, de fato, pertinência crítica se levamos em consideração alguns aspectos que são inerentes à criticidade e ao experimentalismo que diferenciam os novos romances históricos das modalidades antecedentes, pois, segundo Larios (1997), o romance histórico mais recente tem facilitado a criação de novas linguagens fundadas em paradoxos, na ironia, na impugnação da história, na alteridade, na simultaneidade, nos anacronismos, que acabam por construir discursos inovadores do tipo religioso-místico, filológico, de aventura, pseudo-realista, pseudo-cotidiano, etc. (p. 135).

Em oposição a isso, na obra de García Márquez a estrutura da diegese é simples e pouco experimentalista em comparação aos romances da modalidade referida por 
Menton (1993).A obra inicia com Bolívar saindo de Bogotá e se desenvolve linearmente pela viagem do general até o final da mesma, que é o momento da sua morte. Essa sequência de eventos só chega a ser interrompida por algumas breves regressões memorialísticas do general, lembranças do seu passado glorioso. Por outro lado, a voz enunciadora do narrador heterodiegético, única, onisciente e onipresente, impede, de certa forma, o aparecimento das múltiplas perspectivas possíveis que permitiriam o confronto de diferentes versões dos fatos históricos recriados. Além disso, constata-se o receio histórico do escritor colombiano na composição da sua obra. Essa "prudência" documental, não habitual nas produções do novo romance histórico latino-americano, resulta em uma obra que não evidencia o teor desconstrucionista agressivo em relação ao discurso historiográfico - potencial característica dessa modalidade elencada por Menton (1993) na sua obra —, mas que, manipulando o material histórico, aparenta atingir outros fins com a ficcionalização da figura de Bolívar. Mas que fins seriam esses?

Vista tal complexidade na classificação do romance de García Márquez, outras perspectivas críticas foram propostas. Alvarez Borland (1993), divergindo do teórico canadense, afirma que o romance do literato colombiano se aproxima ao que seria uma metaficção historiográfica, termo acunhado por Hutcheon (1991) nos seus estudos sobre a poética do pós-modernismo. Essa proposta viria a ser reforçada por Pulgarín Cuadros (1995) anos mais tarde. Para Borland (1993), El General en su laberinto discute e dramatiza "the process of historical reconstruction by means of a fictional historian who confronts the process of how official history is created" (p. 433). A visão da teórica parte de uma interpretação singular da obra que pode ser considerada acertada desde certos pontos de vista. De fato, a obra de García Márquez apresenta traços metaficcionais explícitos na tessitura do enredo nos quais se discute, efetivamente, a construção da figura histórica de Simón Bolívar como herói da independência. Vejamos:

El más antiguo de sus retratos era una miniatura anónima pintada en Madrid cuando tenía dieciséis años. A los treinta y dos le hicieron otro en Haití, y los dos eran fieles a su edad y a su índole Caribe. Tenía una línea de sangre africana, por un tatarabuelo paterno que tuvo un hijo con una esclava, y era tan evidente en sus facciones que los aristócratas de Lima lo llamaban El Zambo. Pero a medida que su gloria aumentaba, los pintores iban idealizándolo, lavándole la sangre, mitificándolo, hasta que lo implantaron en la memoria oficial con el perfil romano de sus estatuas (García Márquez, 1989, p. 105). 
No trecho, é evidente o uso da metalinguagem com o fim de apontar uma reflexão crítica acerca do processo de construção da heroicidade de Bolívar. No entanto, a simples presença dos recursos metaficcionais em um romance não constituem uma evidência total de estarmos frente a uma metaficção historiográfica. Segundo Fleck (2017),

[...] a metaficção historiográfica se instaura como um conjunto específico de escritas quando os recursos metaficcionais empregados numa obra se constituem no nível global de sentido desse texto, determinando também sua estrutura e as opções narrativas que a sustentam, e não apenas por compor uma releitura crítica do passado no qual se percebem efeitos de autorreferencialidade (p. 78).

Dessa forma, visto que a metaficcionalidade, seja ela discursiva ou narrativa, não é a estratégia mais relevante e recorrente da composição romanesca de García Márquez, e que não há presença de outras características básicas desta modalidade de romance histórico - como a confluência de história, ficção e teoria na argumentação ideológica da voz enunciadora do discurso; as manifestações de personagens e vozes ex-cêntricas; a incorporação da temática pós-moderna da problematização sobre a impossibilidade do conhecimento acerca da realidade do passado na atualidade; entre outras, (Fleck, 2017, p. 83) - El General en su laberinto (1989) não deve ser considerado uma metaficção historiográfica.

Em vista das múltiplas concepções pelas quais o romance tem sido ponderado pela crítica, e a fim de tomarmos uma oportuna postura em relação à obra em questão, faz-se necessário realizarmos uma verificação, conquanto breve, do tratamento dispensado ao material histórico inserido na tessitura do romance e das estratégias escriturais empregadas na sua diegese (Fleck, 2017).

A narrativa de García Márquez, de fato, estabelece novos parâmetros na escrita romanesca histórica na América Latina. Seguindo a linha de pensamento de teóricos como José Miguel Oviedo (1989) e Maria Cristina Pons (1996), entre outros, faz-se evidente que El General en su laberinto (1989) possui um alto nível de criticidade em relação ao que "se diz" na história oficial sobre Bolívar. Segundo Oviedo (1989), o verdadeiro Bolívar era um grande homem, com fraquezas, defeitos e contradições, um ser de carne e osso. Para o crítico, "la proeza de García Márquez consiste en habernos dado ese Bolívar, para escándalo de los historiadores 
empeñados en mantener la pureza marmórea de su estatua” (p. 19). Por sua vez, Pons (1996) afirma que a obra do literato colombiano

[...] no sólo desfamiliariza las versiones 'oficiales' sobre Bolívar, sino que también manipula y altera algunas convenciones del género, discute la relación entre Historia y ficción, y se manifiesta como una reflexión crítica sobre la función de la memoria histórica en la reconstrucción del pasado (p. $\left.16_{4}\right)$.

Os críticos apontam para a efetiva ideologia crítica que compõe o romance de García Márquez e sua potencial natureza desmistificadora que busca rebater a história, as artes e a própria literatura, as quais se encarregaram de construir uma ostentosa figura heroica de Bolívar, irrepreensível em todos os sentidos. Esta visão teórica, compartilhada por diversos outros textos críticos a respeito de El General, pode ser constatada em inúmeras passagens dentro da obra, nas quais a figura de Bolívar é rebaixada e o seu trajeto histórico, descrito pela historiografia, é distorcido de diversas maneiras. Esse processo de inversão de valores no qual o general é vituperado, diminuído e desmistificado se vê reforçado pela utilização de figuras de linguagem e estratégias discursivas como a paródia, a ironia, a heteroglossia, o senso humorístico que chega a avizinhar-se do grotesco, entre outros.

São diversas as passagens de El General en su laberinto em que nos é apresentado um Bolívar humilhado e derrotado. Desde os epítetos satíricos que lhe são atribuídos — “longanizo" (García Márquez, 1989, p. 49), "fantasma” (p. 49), “culo de fierro” (p. 51), "el zambo" (p. 186) —, às cenas de frustração em que o personagem é situado — "No tengo amigos... y si acaso me quedan algunos ha de ser por poco tiempo" (p. 15), "vaya y cuéntele al mundo cómo me vio morir, cagado de gallinas en una playa inhóspita” (p. 24) - entre muitos trechos nos quais o general se vê exposto ao ridículo, caracterizado como um homem à beira da loucura e da morte. Vejamos o trecho a seguir como exemplo desse processo de humanização e rebaixamento ao que a personagem é submetida:

[...] no podían creer que se hubiera desmigajado tanto en tan poco tiempo. Los huesos eran visibles a través de la piel, y no conseguía fijar la mirada. Debía estar consciente de la fetidez y el calor de su aliento, pues se cuidaba de hablar a distancia y casi de perfil. Pero lo que más les impresionó fue la evidencia de que había disminuido de estatura, hasta el punto que al general Montilla le pareció al abrazarlo que le llegaba a la cintura (p. I44). 
Como visto, em El General en su laberinto (1989), nos deparamos com a narração linear do trajeto feito por Bolívar segundo a historiografia, mas sob uma perspectiva evidentemente artística que outorgará ao romance um tom crítico e questionador. Contudo, a intenção que move a releitura desses últimos dias da história do general parece não buscar a desconstrução desafiadora da figura histórica, mas, outorgando certa indulgência, a sua humanização.

Segundo Aínsa (1991), o novo romance histórico latino-americano se caracteriza por "buscar entre las ruinas de una historia desmantelada al individuo perdido detrás de los acontecimientos” (p. 85). García Márquez, pontualmente, procura revelar esse novo perfil do Bolívar-homem que estaria perdido por trás da figura idealizada do Bolívar-herói. Dessa forma, na obra encontramos uma constante reiteração à natureza simples e comum do general que o aproxima do leitor latino-americano quem, finalmente, vê-se espelhado na sua figura. Oviedo (1989) aponta para essa singularidade do texto quando afirma:

El Bolívar de García Márquez no sólo es una creíble figura humana: es un hombre del trópico, exaltado y febril, dado a supersticiones, con una debilidad por la medicina popular y los platillos de la región. [...] era, sin duda, un criollo caribeño cuyo lenguaje y mentalidad reflejaban los hábitos del cuartel y los campos de batalla (p. 23).

Percebemos, dessa forma, que o processo de humanização vem acompanhado de uma "latino-americanização" estrita do sujeito discursivamente projetado. Isto é, Bolívar, antes desenhado sobre as bases eurocêntricas de caráter e conduta, agora é construído a partir de traços preponderantemente latino-americanos, o que provoca a aproximação da figura histórica com o leitor contemporâneo. Dessa forma, temos na obra de García Márquez não só uma desconstrução para a humanização ficcional do herói, mas uma reconstrução da sua figura sob novos aspectos moralizadores e identitários.

Essa nova composição ficcional do general the atribui inéditas características a sua figura, traços que transitam no lugar comum latino-americano. Encontramos, assim, um Bolívar amante da "mazamorra”, comida típica indígena (García Márquez, 1989, pp. 52, 85), do jogo de baralho (pp. 38, 94), da música popular e da dança 
(pp. 45, 151). Esse "novo general", com o qual o leitor latino-americano se encontra identificado, direta ou indiretamente, será a figura ficcional que, na obra de García Márquez, representa o sujeito que entregou tudo de si pela causa independentista e se encontra preso num labirinto metafórico da sua realidade.

García Márquez, desse modo, redimensiona a figura de Simón Bolívar no plano heroico ao separá-lo do perfil idealizado da historiografia e da literatura de cunho tradicionalista - perfil que não se sustentava mais na era contemporânea - e atribuilhe novas características, ancoradas naquelas próprias do homem latino-americano. Percebemos o processo de desconstrução, humanização e reconstrução do caráter heroico da figura histórica a partir da arte romanesca e suas estratégias escriturais e discursivas. Existe, sim, um embate discursivo entre o discurso oficializado e o ficcional na obra de García Márquez, mas a figura do General continua a se manter num pedestal "sagrado", lugar ofertado na ficção pela indulgência dada a Bolívar, que acaba desenhado na tessitura narrativa como o grande herói vituperado e caído.

A respeito da configuração do General na obra de García Márquez, críticos mais contemporâneos, como Alicia Rios (2013) — em cuja obra se discute o culto a Bolívar nas artes e na política de América Latina - comenta:

Efectivamente vemos dibujado allí a un Bolívar "caribe" (no es el prócer clásico en su estatua marmolea) [...]. Pero eso no lo convierte automáticamente en "otro" Bolívar, diferente al que estamos acostumbrados; tal vez nos lo muestre más "real" y humano [...]; no por eso menos idealizado cuando analizamos su desarrollo general dentro de la novela (p. 135).

Com relação à polêmica sobre a possível classificação da obra El General en su laberinto (1989) nas diferentes modalidades de romances históricos críticos, cremos que, na atualidade, já damos um passo mais acertado na construção teórica sobre as releituras críticas da história pela ficção produzidas a partir da década de 80, do século xx. São esses, na sua maioria, romances que não se encaixam naquelas descrições feitas por Hutcheon (1991), como metaficções historiográficas, ou por Menton (1993), como novos romances históricos. Talvez nessas novas diretrizes, como as proporcionadas na obra teórica de Fleck (2017), que estabelece uma terceira fase na trajetória do romance e uma nova modalidade - o romance histórico 
contemporâneo de mediação — , estejam as respostas para uma melhor classificação da obra de García Márquez e para a compreensão da redimensionalização da figura de Bolívar no plano heroico.

\section{La carroza de Bolívar (2012): a desconstrução completa da figura quimérica de um herói}

A literatura que transita entre história e ficção tem sido, na América Latina, um instrumento útil para fomentar a revisão do passado em busca de novas perspectivas e diferentes "verdades" que esclareçam, de algum modo, nossa origem mestiça, plural e híbrida. Essa constante necessidade de encontrar, na memória social e histórica, a essência do caráter latino-americano e dos seus desdobramentos nas distintas regiões deste continente faz com que o labor dos literatos que escrevem suas linhas sobre as tênues fronteiras entre o histórico e o ficcional permaneça vigente. É nesse sentido que o caótico período independentista e as grandes figuras como a de Simón Bolívar continuam sendo reanalisadas na literatura, sob as mais variadas concepções sociais, políticas, históricas e artísticas.

Nessa linha, Evelio Rosero, escritor e jornalista colombiano, publicou em 2012 uma audaz obra em relação à representação romanesca do libertador: La carroza de Bolívar. Assim como a obra do seu conterrâneo García Márquez (1989), o romance de Rosero (2012) parte da intenção de recriar a vida e os feitos de Simón Bolívar, porém, sob um viés altamente crítico e desconstrucionista. As bases escriturais e discursivas de La carroza de Bolivar, no entanto, divergem do proposto pelo Nobel em El General en su labirinto (1989), pois, nesta ficção, nenhuma indulgência será outorgada ao libertador. Em seguida, buscaremos destacar tais distinções, visando evidenciar as intenções ideológicas que movem a releitura histórica empreendida por Evelio Rosero (2012) concernente à figura de Bolívar.

La carroza de Bolívar (2012), galardoado como melhor romance colombiano em 2014, conta a história da personagem Justo Pastor Proceso Lopez, um ginecologista do sul da Colômbia que tem ocupado os últimos 25 anos da sua vida na elaboração de um longo estudo historiográfico sobre Simón Bolívar. A finalidade dessa sua árdua labuta será expor "el monumental error histórico de 
conceder a Bolívar el noble protagonismo de la independencia de los pueblos” (Rosero, 2012, p. 61), dado que, a seu ver, o "libertador” não teria sido mais do que "um ditador criminal”, "um homem arbitrário, covarde e mentiroso”, "semente da corrupção dos governos latino-americanos”.

O notável tom agressivo que é utilizado para descrever a figura de Bolívar, utilizando elementos semióticos negativos, se revela o projeto desconstrucionista do romance, o qual buscará rebaixar o personagem histórico e despojá-lo do caráter heroico que, como pudemos observar em El General, mantinha-se, ainda, nos romances contemporâneos. Esse discurso subversivo da personagem Justo Proceso, que não aceita a imposição da figura de Bolívar como herói da pátria, surge na região Sul do país, especificamente na cidade de Pasto, onde é ambientado o enredo do romance.

Destacamos esse locus discursivo presente no romance devido a que essa região da Colômbia é considerada uma zona periférica em relação ao Centro e ao Norte do país, onde se concentra o poder econômico e político. É, justamente, nesse polo oposto, no Norte - lugar no qual Bolívar possui até hoje uma maior aceitação onde a obra de García Márquez (1989) é ambientada. Em vista disso, ao perceber que o confronto de ideias e visões na escrita ficcional sobre um fato ou personagem histórica pode surgir de um mesmo território nacional, compreendemos as numerosas possibilidades de reconfiguração dessa figura no contexto latino-americano, que abarca diversos povos e países.

O enredo da obra de Rosero (2012) gira em torno a Bolívar. Ainda que sem aparecer ficcionalizado dentro da diegese nem ter espaços de fala, o General será o eixo que movimenta todas as ações e personagens dentro do romance, pois a sua figura teria influenciado, ora de forma negativa ora positiva, a história de cada habitante da cidade de Pasto na época da independência. Assim, Justo Proceso, protagonista do romance, se vê incentivado a acessar a memória latente do povo pastuso, que pouco a pouco teria esquecido quem realmente foi Bolívar. Tal esquecimento é decorrente da implementação do discurso oficial idealizador da figura histórica nas escolas, nas universidades, nos jornais, nas artes, etc. Nesse sentido, a voz narrativa expressa: "El doctor Proceso cayó con estrépito en la dura realidad: allí nadie sabía de Bolívar, excepto las mentiras oficiales aprendidas en la escuela” (Rosero, 2012, p. 68). 
O estudo historiográfico da personagem Justo Proceso, do qual Bolívar é objeto de análise, fundamenta-se em diversas obras históricas como o Estudios sobre la vida de Simón Bolivar (1925), de Rafael Sañudo - personagem de extração histórica cuja ideologia permeia todo o romance -, e em "pesquisas de campo", feitas pelo próprio ginecologista na cidade de Pasto e em municípios próximos. Contudo, em determinado momento da diegese, Justo Proceso compreende que não será através de uma extensa e complexa obra histórica que "a verdade sobre Bolívar” será revelada.

A personagem é levada a perceber, por meio de distintas ações no plano narrativo, que, para despertar a consciência dos pastusos e trazer à tona a memória do seu passado, deverá ir além do discurso oficial da história. Assim surge a ideia de construir um carro alegórico que exponha "as barbáries que cometeu o chamado libertador" e que desfile no popular carnaval de Negros y Blancos; uma "carroza de Bolívar”, um carro alegórico. Frente a essa possibilidade, o narrador expõe:

\begin{abstract}
Con la carroza de marras, pensaba, Simón Bolívar, simple y llanamente, resultaría divulgado como una fábula, pero una fábula de verdad, hilvanadas cada una de sus más infames y evidentes maniobras, Simón Bolívar, se dijo, revelado al fin, Simón Bolívar tal cual: su extraordinaria capacidad para convencer a sus contemporáneos y de paso a las generaciones venideras (con cartas y proclamas ampulosas, intrigantes, delirantes y tramposas, pomposas y pedantes, ditirámbicas, simulacros de Alejandro Magno y Napoleón) de que era alguien que no era, que había hecho lo que no hizo, y pasar a la historia como el héroe que no fue (Rosero, 2012, pp. $\left.\sigma_{2}-\sigma_{3}\right)$.
\end{abstract}

Rosero (2012) propõe uma analogia fundamental na sua obra. Ao desprestigiar o impacto que poderia ter uma obra histórica oficial — como a que a personagem Justo Proceso elaborou - e substituí-la por uma representação artística — como será o carro alegórico de Bolívar - o literato ressalta a importância das representações ficcionais sobre o passado como vias para a conscientização dos povos latino-americanos, em detrimento da voz hegemônica da história. Em outras palavras, evidencia-se, na obra de Rosero, a relevância que tem a escrita do gênero romance histórico no território latino-americano, onde é, "mais do que uma experiência de prática de produção romanesca híbrida de história e ficção, um possível caminho para a descolonização” (Fleck, 2017, p. 104). 
O romance vale-se de diversas estratégias escriturais e discursivas para ampliar o seu potencial desconstrucionista e subversivo em relação à história hegemônica. A multiplicidade de perspectivas com relação ao fato histórico é apreciável em La carroza de Bolívar, diversamente do exposto por García Márquez (1989) em El General en su laberinto, obra na qual a recapitulação histórica se dá a partir de uma única voz enunciadora que é representada ora pelo narrador ora por algum personagem da diegese.

No romance de Rosero (2012) são distintas as vozes que participam da construção do discurso, muitas vezes sendo contraditórias entre elas, o que permite dissipar a ideia de uma única verdade sobre quem foi "realmente" Bolívar. Estas vozes, que representam distintas perspectivas discursivas, vêm representadas por personagens de distintas classes sociais, distintos gêneros, distinta formação intelectual, etc. Vejamos a seguinte passagem do romance onde a presença dessas múltiplas vozes pode ser verificada, a partir da figura de Zulia Iscuandé, mulher de classe social baixa e pouca instrução intelectual formal:

Entonces oyeron a Zulia Iscuandé, que en todo ese tiempo no pronunciaba palabra.

- Mi abuelo siempre habló de Bolívar - dijo.

Entrecerró los ojos, como si se acordara:

- A mí misma me habló de Bolívar - dijo.

Y luego, decidida, encontrando el recuerdo, asiéndolo:

- Se la pasaba hablando de Bolívar, pero decía que ese Bolívar había sido un gran hijueputa.

Tembló el taller con la explosión de una risotada. Al doctor Justo Pastor Proceso López se le aguaron los ojos.

"Dios”, pensó, "todavía hay memoria entre nosotros" (Rosero, 2012, p. 69).

Ademais do dinamismo polifônico e discursivo, o efeito cômico que produz a ruptura do formalismo corrobora a intenção transgressora do romance a respeito da figura de Bolívar. O uso da linguagem comum, coloquial, indica o locus enunciativo onde se diz nascer o discurso desmistificador e desconstrucionista do romance: no seio do povo, nos homens e mulheres que sentiram de mais perto as "barbáries do mal chamado libertador". 
Tais recursos literários compõem a tessitura do romance, resultando numa produção que desafia a veracidade e a precisão do discurso histórico em torno da vida e dos feitos da figura do maior líder independentista consagrado na memória e no imaginário latino-americano. Para mais, em La carroza não só se questiona o fazer historiográfico, mas se relê a própria literatura, num processo intertextual altamente crítico. Segundo Genette (2010), entre os tipos de transtextualidade encontramos a intertextualidade, que é a "co-presença entre dois ou vários textos", e a metatextualidade, que "é, por excelência, a relação crítica" (pp. 14-16). Ambos tipos de transcendência textual são evidenciados em La carroza com relação à obra icônica El general en su laberinto (1989). Além da citação direta da obra de García Márquez, em La carroza encontramos um agressivo comentário que questiona o discurso arquitetado em El general em torno à figura de Bolívar.

Rosero (2012) dedica o primeiro capítulo da segunda parte do romance (que se divide em três partes) a dissertar e comentar, por meio das vozes das personagens, diversos textos históricos que exibem o caráter negativo, ambicioso e ditatorial de Bolívar; entre eles, Marx (1858) e Sañudo (1925). Após a longa discussão, o capítulo finaliza com a seguinte asseveração, uma citação crítica direta das palavras da "pluma pluscuamperfecta del taumaturgo hechicero”, referindo-se a García Márquez (1989, p. 8), em relação a Bolívar:

Así describieron Carlos Marx y José Rafael Sañudo, cada uno a su manera, al Libertador Simón Bolívar, basados en testimonios y documentos irrefutables. Lo que no impediría que muchos años después la pluma pluscuamperfecta del taumaturgo hechicero escribiera que el general Bolívar "siempre tuvo a la muerte como un riego profesional sin remedio. Había hecho todas sus guerras en la línea de peligro, sin sufrir ni un rasguño, y se movía en medio del fuego contrario con una serenidad tan insensata que hasta sus oficiales se conformaron con la explicación fácil de que se creía invulnerable. Andaba sin escolta, y comía y bebía sin ningún cuidado de lo que le ofrecían donde fuera. [...] su desinterés no era inconsciencia ni fatalismo, sino la certidumbre melancólica de que había de morir en su cama, pobre y desnudo, y sin el consuelo de la gratitud pública" (Rosero, 2012, pp. 166-167).

Decorrente dos aspectos até aqui apontados, entre outros, consideramos La Carroza de Bolivar (2012) como um romance histórico "desconstrucionista pleno", termo que, ao nosso ver, abarca o caráter narrativo e ideológico da obra. 


\section{Considerações finais}

A releitura do próprio discurso ficcional na literatura evidencia a constante busca dos povos latino-americanos pelas raízes da sua identidade espelhada nos grandes personagens históricos. Em La carroza se questiona o próprio discurso contemporâneo com relação à figura de Simón Bolívar arquitetado por um dos literatos mais relevantes a nível nacional, continental e mundial: Gabriel García Márquez. As barreiras do proibido, do legítimo e do oficial são infringidas e fragmentadas pela arte romanesca que produz novas perspectivas, novos questionamentos e plurais "verdades" oriundas do contexto latino-americano.

A desconstrução literária em ambas as obras produz efeitos estéticos que divergem, afirmando a repercussão que os feitos do Libertador ainda possuem na nossa contemporaneidade, ao mesmo tempo que mostram como o fazer artístico continua a buscar novas veredas para a descolonização ideológica dos povos latino-americanos.

\section{Referências}

Aínsa, F. (1991). La nueva novela histórica latinoamericana. Plural 240, pp. 82-85.

Álvarez-Borland, I. (1993). The Task of the Historian in "El general en su laberinto". Hispania 76, pp. 439-445.

Anônimo. (2012) Xicoténcatl. Edición, estudio preliminar y notas de Gustavo Forero Quintero. Madrid: Vervuert.

Cobo Borda, J. G. (1998). Los nuevos Bolívares. Cuadernos Hispanoamericanos 472, pp. 7-25.

Fleck, G. F. (2017). O Romance Histórico Contemporâneo de Mediação: Entre a Tradição e o Desconstrucionismo - Releituras Críticas da História pela Ficção. Curitiba: CRV.

García Márquez, G. (1989). El General en su laberinto. Bogotá: Editorial Oveja Negra.

Genette, G. (2010). Palimpsestos: a literatura de segunda mão. Belo Horizonte: Edições Viva Voz.

González, L. S.; Fleck; G. F. (2017). La Malinche em Xicoténcatl (1826) e na história: o imaginário coletivo mexicano em configurações confrontadas. Criola 19, pp. 115-132.

Larios, M. A. (1997). Espejo de dos rostros. Modernidad y postmodernidad en el tratamiento de la historia. En: K. Kohut (Ed). La invención del pasado. La novela bistórica en el marco de la posmodernidad (pp.130-136). Frankfurt/Madrid: Vervuert.

Menton, S. (1993). La nueva novela histórica de la América Latina: 1979-1992. México: Fondo de Cultura Económica. 
Oviedo, J. M. (1999). García Márquez en el laberinto de la soledad. Antbropos: Huellas del conocimiento 187, pp. 68-74.

Pons, M. C. (1996). Memorias del olvido. La novela histórica de fines del siglo Xx. México: Siglo XXI.

Pulgarín, A. (1995). Metaficción bistoriográfica: la novela histórica en la narrativa hispánica posmoderna. Madrid: Espiral Hispano-Americana.

Ríos, A. (2013). Nacionalismos banales: el culto a Bolivar. Literatura, cine, arte y política en América Latina. Pittsburgh: Nuevo Siglo.

Rosero, E. (2012). La carroza de Bolivar. Barcelona: Tusquets Editores.

Wasserman, C. (2011). A primeira fase da historiografia latino-americana e a construção da identidade das novas nações. História da bistoriografía 7, pp. 94-115. 